\title{
Community characteristics of old-growth western juniper
}

\section{woodlands}

\author{
WENDY SIMS WAICHLER, RICHARD F. MILLER, AND PAUL S. DOESCHER
}

Authors are graduate student, professor of Rangeland Resources at the Eastern Oregon Agricultural Research Center, and professor of Rangeland Resources, Oregon State University.

\begin{abstract}
While considerable attention has been given to the areal expansion of juniper (Juniperus sp.) in the western United States, the presence and ecological significance of old-growth juniper communities has gone largely unnoted. Increased recognition of these communities has prompted questions about how to recognize oldgrowth, community structure, ecological importance, and appropriate management. As an initial analysis of old-growth western juniper woodlands (Juniperus occidentalis Hook var. occidentalis Vasek) in central Oregon, this study investigated old-growth community structure on eolian-sand derived soils. These woodlands represent the most extensive old-growth western juniper woodlands throughout its range. Nine study plots were established at 7 sites. Within each plot, densities and physical attributes of all live trees and large standing and fallen woody detritus were recorded. Additional measurements for live trees included canopy cover, apparent age class (pre- or postsettlement), and a sampling of tree ages. Aging of trees older than 250 years was complicated by extensive heartwood rot. Shrub density and cover were measured by species. Understory cover was measured by species and functional type. Bare ground, rock, juniper litter, other litter, moss, and cryptogamic crust cover were also measured. Plant cover ranged from 11 to $33 \%$ for trees, 0 to $10 \%$ for shrubs, 3 to $12 \%$ for perennial grasses, 1 to $2 \%$ for forbs, and from 0 to $0.1 \%$ for annual grasses. The woodlands contained at least 80 trees ha ${ }^{-1}$ aged over 200 years. Correlations between tree parameters and understory structure and composition were generally poor. Differences in plant composition among these stands was primarily attributed to elevation, slope, and percent sand content. Structural characteristics that distinguished old-growth stands from younger stands included tree growth form, presence of standing and dead large woody debris, lichen on dead branches, and a relatively open canopy. Results provide a preliminary basis for identifying old-growth Juniperus occidentalis stands, as a prelude to the development of management plans and further research into the functional characteristics of the systems. A definition of old-growth juniper woodlands is presented.
\end{abstract}

Key Words: Juniperus occidentalis, structure, pinyon-juniper

In the Intermountain West, it is estimated that 3 to $5 \%$, or nearly 160,000 ha, of western juniper woodland is old-growth (USDIBLM 1990, Miller et al. 1999). However, attention has primarily

This research was supported by the Eastern Oregon Agricultural Research Center (EOARC), and Bureau of Land Management Districts Lakeview, Ore, and Prineville, Ore. EOARC is jointly operated by Oregon State University and USDA Agricultural Research Service.

Oregon State Agricultural Experiment Station Technical Paper Number 11719

Manuscript accepted 10 Dec. 2000

\section{Resumen}

Mientras que en el oeste de Estados Unidos se ha dado considerable atención a la expansión aérea del "Juniper" (Juniperus sp.), la presencia y el significado ecológico de las comunidades viejas de "Juniper"'han sido muy ignoradas. Un aumento en el reconocimiento de estas comunidades ha despertado preguntas acerca de como reconocer el crecimiento viejo, la estructura de la comunidad, la importancia ecológica y el manejo apropiado. Como un análisis inicial de los bosques de viejos del "Western juniper" (Juniperus occidentalis Hook var. occidentalis Vasek) de la parte central de Oregon este estudio investigó la estructura de la comunidad de crecimiento viejo en suelos arenosos eólicos. Estos bosques representan los mas extensos bosques decrecimiento viejo de "Western juniper" a través de su rango. Se establecieron 9 parcelas de estudio en 7 sitios. Dentro de cada parcela se registraron las densidades y atributos físicos de todos los árboles vivos, de pie y caidos en descomposición. Medidas adicionales tomadas en los árboles vivos fueron: cobertura de la copa, clase de edad aparente ( pre o post-colonización) y un muestreo de la edad de los árboles. Estimar la edad de árboles de mas de 250 años fue complicado por la extensiva pudrición del centro del árbol. La densidad de arbustos y la cobertura fueron medidas por especie. La cobertura de la vegetación baja se midió por especie y tipo funcional. También se midieron: el suelo desnudo, rocas, mantillo de "Juniper", otro tipo de mantillo, musgos y costra criptogamica. La cobertura vegetal vario de 11 a $33 \%$ para árboles, de 0 a $10 \%$ para arbustos, 3 a $12 \%$ para zacates perennes, 1 a $2 \%$ para hierbas y de 0 a $0.1 \%$ para zacates anuales. Los bosques contenían al menos 80 árboles ha-1 de una edad de más de 200 años. Las correlaciones entre los parámetros de los arboles y la estructura de la vegetación baja y composición fueron generalmente pobres. Las diferencias en la composición de plantas entre estas poblaciones fueron principalmente atribuidas a la elevación, pendiente y porcentaje de arena contenida en el suelo. Las características estructurales que distinguieron a las poblaciones de árboles viejos de las de arboles nuevos incluyeron la forma de crecimiento de los árboles, la presencia de biomasa muerta y residuos grandes de madera muerta, líquenes en las ramas muertas y una copa relativamente abierta. Los resultados proveen una base preliminar para identificar las poblaciones viejas de Juniperus occidentalis como un preludio para el desarrollo de planes de manejo y futura investigación dentro de las características funcionales de los sistemas. Se presenta una definición de bosque de crecimiento viejo de "Juniper". 
focused on the rapidly expanding postsettlement stands of juniper throughout the western United States (Miller and Wigand 1994). Resource inventories, management plans, range improvement practices, research, and wildlife habitat evaluations typically have not differentiated between old-growth juniper and postsettlement woodlands.

Kaufmann et al. (1992) and Spies et al. (1988) noted that old-growth conifer communities provide unique, and often irreplaceable biological/ecological values, such as animal and plant habitat, biodiversity and genetic pools, and long-term climate records. The Forest Service has defined old-growth forests as ecosystems distinguished by old trees and related structural attributes. Old-growth encompasses the later stages of stand development that typically differ from earlier stages in a variety of characteristics which may include tree size, accumulations of large dead woody material, number of canopy layers, species composition, and ecosystem function (USDA Forest Service 1993). Structural attributes of old-growth are reported to vary with forest type, climate, site conditions, and disturbance regime. Although assessing tree age within a stand is an important index of old-growth development, tree age alone is insufficient for assessing old-growth, even within a species. Structural attributes are more commonly described than functional attributes, due to their relative ease of measurement (USDA Forest Service 1993).

The northern variant of western juniper (Juniperus occidentalis Hook var. occidentalis $\mathrm{Vasek}^{1}$ ) occupies approximately 3.2 million ha (Bolsinger 1989, Gedney et al. 1999) in southeastern Washington, eastern Oregon, northeastern California, southwestern Idaho, and northwestern Nevada. In the literature, communities typically reported to contain old-growth are described as open juniper shrub savannas occurring on shallow rocky soils or growing along rimrock (Holmes et al. 1986, Miller and Rose 1995). These sites are frequently described as fire-safe because of limited accumulations of understory fuels. However, in the eolian pumice sand region of the Mazama and northwestern edge of the High Desert Ecological Provinces, western juniper oldgrowth woodlands ${ }^{2}$ form relatively extensive stands greater than $100 \mathrm{~km}^{2}$ and ages

\footnotetext{
${ }^{1}$ Nomenclature follows Hitchcock and Cronquist 1973, and Cronquist et al. 1977.

${ }^{2}$ Woodlands are defined as having a tree canopy cover of $\geq 10 \%$, stands with $<10 \%$ tree canopy cover are defined as savannas (Gedney et al. 1999).
}

of individual trees can exceed 1,000 years. The growth form of old trees is often characterized by a generally nonsymmetrical appearance, rounded spreading canopies, canopies that are often sparse, large irregular tapering trunks, deeply furrowed and fibrous bark, few but heavy branches, and the presence of a bright-green arboreal fruticose lichen (Letharia sp.) (Burkhardt and Tisdale 1969, Holmes et al. 1986, Miller et al. 1999). Trees may also support large basal branches and a narrow strip of cambium attached to a single living branch. However, stand structural characteristics including standing and downed dead, decadence of living trees, cavities, and branches covered with lichens have not been quantified for these old-growth woodlands.

The purpose of this study was to define stand characteristics for minimally dis- turbed old-growth western juniper woodlands in the eolian sand region of central Oregon. Specific objectives were to: (1) quantify overstory and understory structure and composition; (2) determine if structure and composition vary across these woodlands; (3) evaluate the relationship between biotic and abiotic characteristics with plant species composition and structure; and (4) develop a functional definition of old-growth western juniper woodlands in the aeolian sand region of central Oregon.

\section{Study Area}

The study was conducted at 7 sites in the eolian sand region in the Mazama and northwestern portion of the High Desert Provinces (Anderson et al. 1998) in central

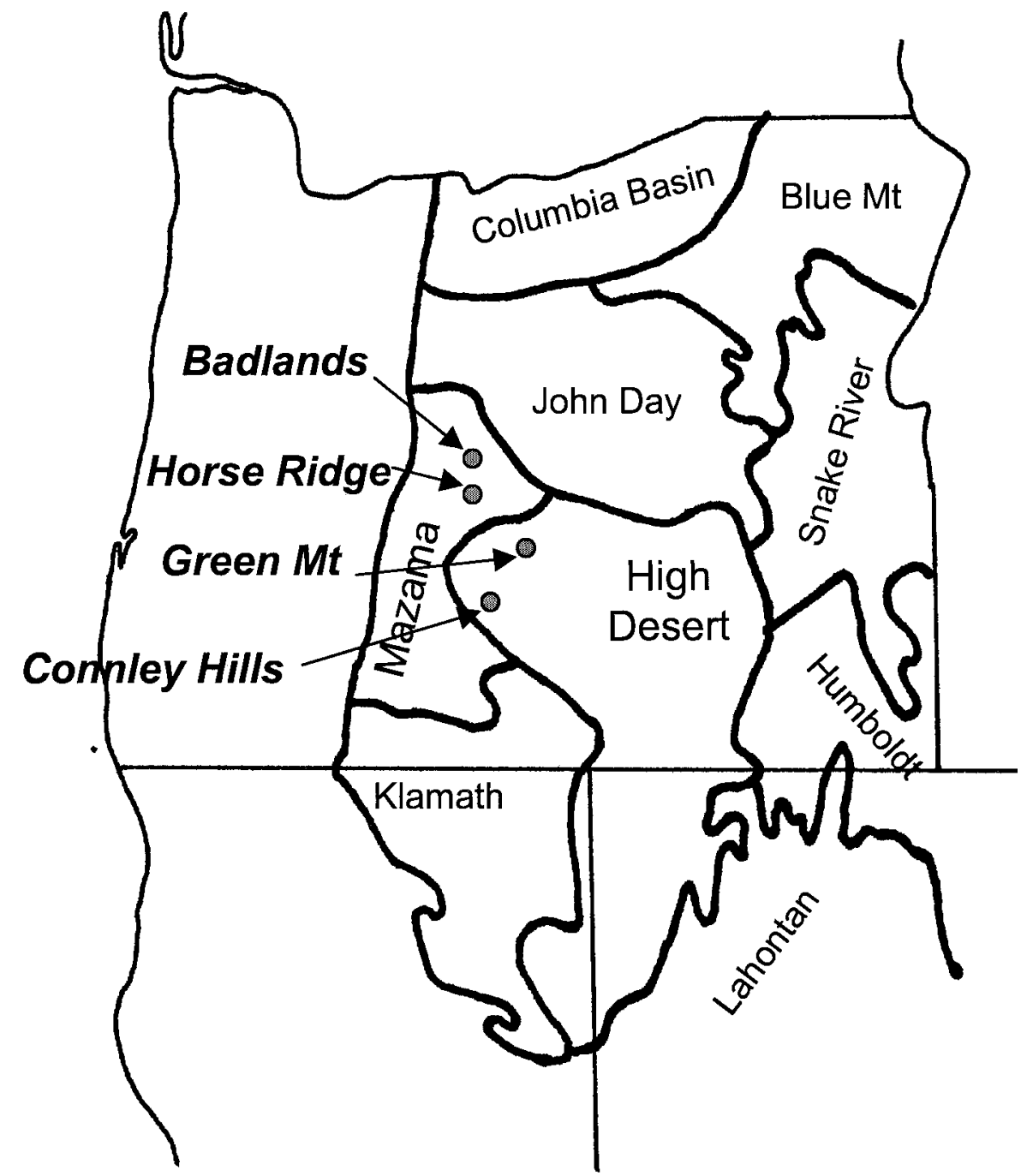

Fig. 1. Location of study sites in Mazama and High Desert Ecological Provinces of Oregon (Anderson et al. 1998). 
Table 1. Study site characteristics. Topographic data are presented as the mean value for the 9 plots at each site. Soils data is based on one or more soil pits dug at each site. Listed plants are western juniper (JUOC), mountain big sagebrush (ARTRV), gray rabbitbrush (CHNA), Idaho fescue (FEID), bluebunch wheatgrass (AGSP), and Junegrass (KOCR).

\begin{tabular}{|c|c|c|c|c|c|c|c|}
\hline Site & $\begin{array}{l}\text { Connley Hills } \\
\text { East }\end{array}$ & $\begin{array}{l}\text { Connley Hills } \\
\text { West }\end{array}$ & $\begin{array}{l}\text { Horse Ridge } \\
\text { North }\end{array}$ & Badlands & $\begin{array}{l}\text { Green Mtn. } \\
\text { North-mounds }\end{array}$ & $\begin{array}{c}\text { Green Mtn. } \\
\text { North-interspaces }\end{array}$ & Green Mtn. \\
\hline$\overline{\text { Code }}$ & $\mathrm{CHE}$ & $\mathrm{CHW}$ & HRN & BAD & GMNm & GMNi & GMS \\
\hline$\overline{\text { Disturbance }}$ & negligible & negligible & negligible & $\begin{array}{c}\text { minimal } \\
\text { cutting }\end{array}$ & negligible & cattle grazing, & cattle grazing, \\
\hline Slope (\%) & 31 & 42 & 17 & 0 & 7 & 3 & 2 \\
\hline Aspect $\left(^{\circ}\right)$ & 95 & 261 & 14 & 0 & 48 & 123 & 174 \\
\hline Elevation (m) & 1551 & 1557 & 1266 & 1177 & 1517 & 1515 & 1477 \\
\hline Terrain & steep east slope & steep west slope & north slopes & lava mounds & lava mounds & shallow slope & shallow slope \\
\hline Soil texture & loamy sand & loamy sand & loamy sand & sandy loam & loamy sand & loamy sand & loamy sand \\
\hline $\begin{array}{l}\text { Soil depth }(\mathrm{cm}) \\
\text { Plant community }\end{array}$ & $\begin{array}{c}75+ \\
\text { JUOC/FEID- } \\
\text { AGSP }\end{array}$ & $\begin{array}{c}67+ \\
\text { JUOC/AGSP- } \\
\text { KOCR }\end{array}$ & $\begin{array}{c}60 \\
\text { JUOC/ARTRV } \\
\text { /FEID-AGSP }\end{array}$ & $\begin{array}{c}0+ \\
\text { JUOC/ARTRV } \\
\text {-CHNA/ } \\
\text { AGSP-FEID }\end{array}$ & $\begin{array}{c}0 \text { to } 42 \\
\text { JUOC/ARTRV } \\
\text { /FEID }\end{array}$ & $\begin{array}{c}85 \\
\text { JUOC/ARTRV } \\
\text { /FEID }\end{array}$ & $\begin{array}{c}70+ \\
\text { JUOC/FEID }\end{array}$ \\
\hline
\end{tabular}

Oregon (Fig. 1) between latitudes of $43^{\circ}$ and $44^{\circ}$ and longitudes of $120^{\circ} 45^{\prime}$ and $121^{\circ}$. Although the Green Mountain and Connley Hills study sites are located in the High Desert Province because of topographic features the pumice sandy soils are similar to those typically found in the Mazama Province. This region supports the most extensive stands of old-growth western juniper woodlands throughout its range (Miller et al. 1999). Seven study sites were located in the 4 largest oldgrowth stands in this region (Waichler 1998). Two sites were located at Connley Hills, 3 at Green Mountain, and 1 each at Horse Ridge and the Badlands. Two sites were on the north side of Green Mountain; one on rock outcrops and the other between the outcrops. The third site at Green Mountain was located on the south side and did not include rock outcrops. At the Horse Ridge site, plots were located along the apex of 3 adjacent convex ribs of the north slope. At the Badlands site, juniper trees occurred on basaltic lava mounds, or tumuli, that punctuated nearly barren sandy interspaces. Site codes used throughout the remainder of this report (unless otherwise noted) and other information on the sites are shown in Table 1.

Climate in the study area is characteristic of the northern Great Basin. Precipitation has averaged 20 to $28 \mathrm{~cm}$ per year, predominantly as winter and spring snow and rain (Taylor 1993). The Natural Resource Conservation Service (NRCS) site description for the Shallow Pumice Hills 25 to $28 \mathrm{~cm}$ precipitation zone at Horse Ridge notes air temperatures averaging $8^{\circ} \mathrm{C}$ annually, with extremes ranging from -32 to $38^{\circ} \mathrm{C}$. Soil thermal regimes are frigid, except for a mesic regime in the Badlands.

Soils at all sites were derived from volcanic ash deposits of aeolian origin. Soils typically vary between well drained and excessively well drained (Table 1). Soil on the rock outcrops in the Badlands and Green Mountain North had accumulated in shallow rock depressions. Soils are mapped by NRCS as a complex of Vitrixerandic Haploxerolls (typically 36 $\mathrm{cm}$ to bedrock), Lithic Torripsamments, and lava flows (rock outcrop) in the Badlands, Vitritorrandic Haploxerolls (typically $81 \mathrm{~cm}$ to bedrock) and rock outcrop on Green Mountain, and Vitrandic Haploxerolls on Connely Hills.

In the central Oregon juniper zone, western juniper is the dominant tree species, with occasional ponderosa pine (Pinus ponderosa Dougl.) in favorable locations (Driscoll 1964b). Natural wide spacing of the junipers provides a savanna-like appearance. The most common dominant shrub is mountain big sagebrush (Artemisia tridentata subsp vaseyana (Rydb) Beetle). Other common shrubs include bitterbrush (Purshia tridentata (Pursh) DC.), gray rabbitbrush (Chrysothamnus nauseosus (Pall.) Britt), green rabbitbrush (Chrysothamnus viscidiflorus (Hook.) Nutt.), and horsebrush (Tetradymia canescens DC). In relatively undisturbed communities, bluebunch wheatgrass (Agropyron spicatum (Pursh) Scribn. \& Smith) and Idaho fescue (Festuca idahoensis Elmer) are dominant grasses. Sandberg bluegrass (Poa sandbergii Vasey) and Thurber needlegrass (Stipa thurberiana Piper) are common. Forbs are not a major constituent of undisturbed communities. Common forbs include buckwheats (Eriogonum), wild dandelions (Agoseris), locoweed (Astragulus), lupine (Lupinus) species, yarrow (Achillea millefolium L.), rock gilia (Leptodactylon pungens (Torr.) Nutt.), and Oregon sunshine (Eriophyllum lanatum (Pursh) Forbes).

\section{Methods}

\section{Plot layout}

Three, $1000 \mathrm{~m}$ transects were established within each of the 7 study sites. Transects were systematically laid out to allow complete coverage of each oldgrowth stand. Three sampling plots were placed on each transect (9 plots per site) except at Green Mountain North where 6 plots were established along each transect, 3 each on and off of the rocky outcrops. Plot locations were selected arbitrarily, but with plots ranging from the first third to the last third of each transect. Plot centers were located by a blind toss of a meter pole. Plot diameters for tree measurements were $20 \mathrm{~m}$. The interspace plots at Green Mountain were located away from the edges of the mounds. At the Badlands site, plots were established on the large lava mounds along each transect. Three, $30 \mathrm{~m}$ lines were laid out across each plot. One line was placed through the center of the circular plot, along the terrain contour. The other 2 lines were placed parallel to and 15 $\mathrm{m}$ on either side of the center line. At some plots on rocky mounds, adjustments in position had to be made to ensure the entire line was contained on the mound. We made a general search of the area adjacent to each plot for evidence of fire.

\section{Plot measurements}

Tree measurements recorded within circular plots were the number of live trees over $1 \mathrm{~m}$ tall, standing dead trees $(\geq 25 \mathrm{~cm}$ diameter at $30 \mathrm{~cm}$ above ground level), and large fallen trees pieces. The fallen pieces included full or split tree boles and large limbs $(\geq 3.3 \mathrm{~m}$ length and $25 \mathrm{~cm}$ diameter at large end). Tree heights were estimated using a 3-meter pole placed adjacent to each tree. Trees $<15 \mathrm{~cm}$ tall 
were counted within the 2 x $30 \mathrm{~cm}$ shrub plots. Diameters of standing trees were read at $30 \mathrm{~cm}$ above ground level using a pole calibrated in $10 \mathrm{~cm}$ increments. Fallen piece diameters were measured with a tape measure at $30 \mathrm{~cm}$ above apparent ground level. Each live tree within the plot was assigned to a postsettlement (establishing after 1870) or presettlement (establishment prior to 1870) age class based on growth form. Trees placed in the postsettlement age class had symmetrical conical canopies and obvious terminal and lateral leader growth. Presettlement trees had rounded tops and little leader growth. Presettlement trees commonly exhibit deeply furrowed and stringy bark. Additional characteristics may include large lower limbs, dead tops, and strip bark supporting a limited canopy. Live trees were visually placed into a form category based on fullness of the canopy as follows: Form 1 -over $90 \%$ of the canopy living, Form 2-50 to $90 \%$ of canopy live, Form $3-10 \%$ to less than $50 \%$ of canopy live, Form 4 - under $10 \%$ of canopy live. Canopy size was measured as foliage spread along and perpendicular to the direction of maximum foliage spread. This technique generally overstates canopy area on trees that do not have a full canopy. On plots where tree cores were collected, an attempt was made to sample all trees. Tree cover was measured using the line intercept method along each $30 \mathrm{~m}$ transect (Canfield 1941).

Shrub cover was measured on each 30 $m$ transect using the line intercept method. Both densities of shrubs and juniper trees $30 \mathrm{~cm}$ to $100 \mathrm{~cm}$ tall were measured in a 2 $m$ wide belt transect centered on each 30 $\mathrm{m}$ transect. Live herbaceous, litter, rock and bareground cover were estimated in $30,0.2 \mathrm{~m}^{2}$ plots placed at $3 \mathrm{~m}$ intervals along each $30 \mathrm{~m}$ transect.

One or more soil pits were dug at each site to determine soil depth and texture. Texture was measured for each horizon using the hydrometer method of particle size analysis (Gee and Bauder 1986).

\section{Data Analysis}

Data were reduced to means and standard errors by site. Analysis of variance and regression analysis were used to test for relationships between understory attributes with abiotic or tree structural attributes. These analyses were done using the SAS System for Windows, Version 6.12 with a significance level of 0.05 (SAS 1996).

To show the arrangement of the plots based on species composition and allow comparison of the within-site and betweensite distribution, ordination was done using the Nonmetric Multidimensional Scaling (NMS) technique (Kruskal 1964, Mather 1976). This iterative technique ordinates based on ranked distances between sites, avoiding the assumption of data normality. "Stress" is used in NMS as a measure of departure from monotonicity in the relationship between the distance between plots in the original many-dimensional space and the distance in the reduceddimensional space. Analysis was done using PC-ORD for Windows, Version 3.03 (McCune and Mefford 1995). Species diversity indices were also calculated using this program.

Data were first reduced into 2 matrices. A species cover matrix contained the percent cover of each understory species and the tree density for each plot. This measure of tree importance was used because it was the most accurate of the measurements taken and because linear regressions had shown it to have better correlation with environmental parameters than the other tree parameters studied. To reduce the high skew (5.0) and coefficient of variation $(460 \%)$ in the totals of species, several adjustments were made. Species occurring in fewer than $5 \%$ of the plots (fewer than 4 plots) were deleted, leaving 56 species in the matrix. Juniper density data was log transformed. Species cover data was transformed as follows:

transformed value $=\log$ (original value + minimum non-zero cover value in matrix) - log (minimum nonzero cover value in matrix).

This transformation allowed initial values of zero to remain zero. The second matrix contained plot environmental data and other plot parameters. This matrix contained slope (degrees), heat load on a scale of zero to one [1 - cos (aspect angle 45)/2], elevation, species richness, total understory plant cover, tree density, tree basal area, tree canopy area, and ground cover by rock, bare ground, moss, crust, juniper litter, and other litter for each plot.

An initial run was made using 6 dimensional space, Sorensen distance, and 100 iterations. Plots of stress versus iteration were examined for instability and to find the lowest number of axes at which the reduction in stress gained by adding another axis was small. A final run of 100 iterations was made using 3 axes with a randomly selected starting configuration. Monte Carlo simulation was included as a check on whether a similar final stress could have been obtained by chance. The stress obtained with the data set was com- pared to the stress from 20 runs of randomized versions (data shuffled within columns) of data. Additional runs were compared to ensure that the solution was not at local minima. Overlays of individual species, plant functional types, and environmental variables on the resulting ordination allowed for an examination of the correlation between these variables and the ordination axes.

\section{Results}

\section{Woodland structure and composi- tion}

Structural attributes among the oldgrowth western juniper woodlands were summarized for (Tables 2 and 3). Juniper cover averaged $23 \%$ (range 11 to $33 \%$ ), while density averaged 209 live trees over $1 \mathrm{~m} \mathrm{high} \mathrm{ha}^{-1}$ (range 102 to 302). Mean height and diameter were $5 \mathrm{~m}$ and $36 \mathrm{~cm}$, respectively. Age of trees $<1 \mathrm{~m}$ tall greatly varied in age from recently established trees $(<25$ years old) to older trees suppressed.

The majority of woody detritus was retained in standing live or dead trees, with a smaller proportion composed of large pieces on the ground. Standing dead trees and large fallen pieces occurred in the plots at all sites except one. High variability within and between sites occurred for both types of debris. Overall, the mean density of standing dead trees $(13 \pm 8$ trees/ha) was over twice the mean density of fallen detritus $(6 \pm 14$ pieces/ha). Standing dead trees also tended to be larger than the fallen pieces, which could include several pieces from a single tree.

A third component of aboveground woody debris, attached debris such as dead limbs and spires on live trees, was not measured but appeared to be the most prevalent in these woodlands. Lichens (Letharia columbiana (Nutt.) J.W. Thomson and L. vulpina (L.) Hue) were frequently found on dead wood. One example of attached debris was wood that had been dead for over 600 years (determined by cross-dating) on a 1600-year-old tree found adjacent to a plot on the Horse Ridge North site. A qualitative measure of this component may be provided by the form classes of the trees found at the site. Sixteen percent of live trees (height at least $1 \mathrm{~m}$ ) in the study plots had canopies less than $50 \%$ complete, with many dead branches retained in the leafless portion of the canopy. Another $40 \%$ of trees were missing 10 to $50 \%$ of the canopy and also retained dead branches. 
Table 2. Plant cover (\%), species richness, and diversity. Listed shrubs are mountain big sagebrush (ARTRV), gray rabbitbrush (CHNA), green rabbitbrush (CHVI), and bitterbrush (PUTR).

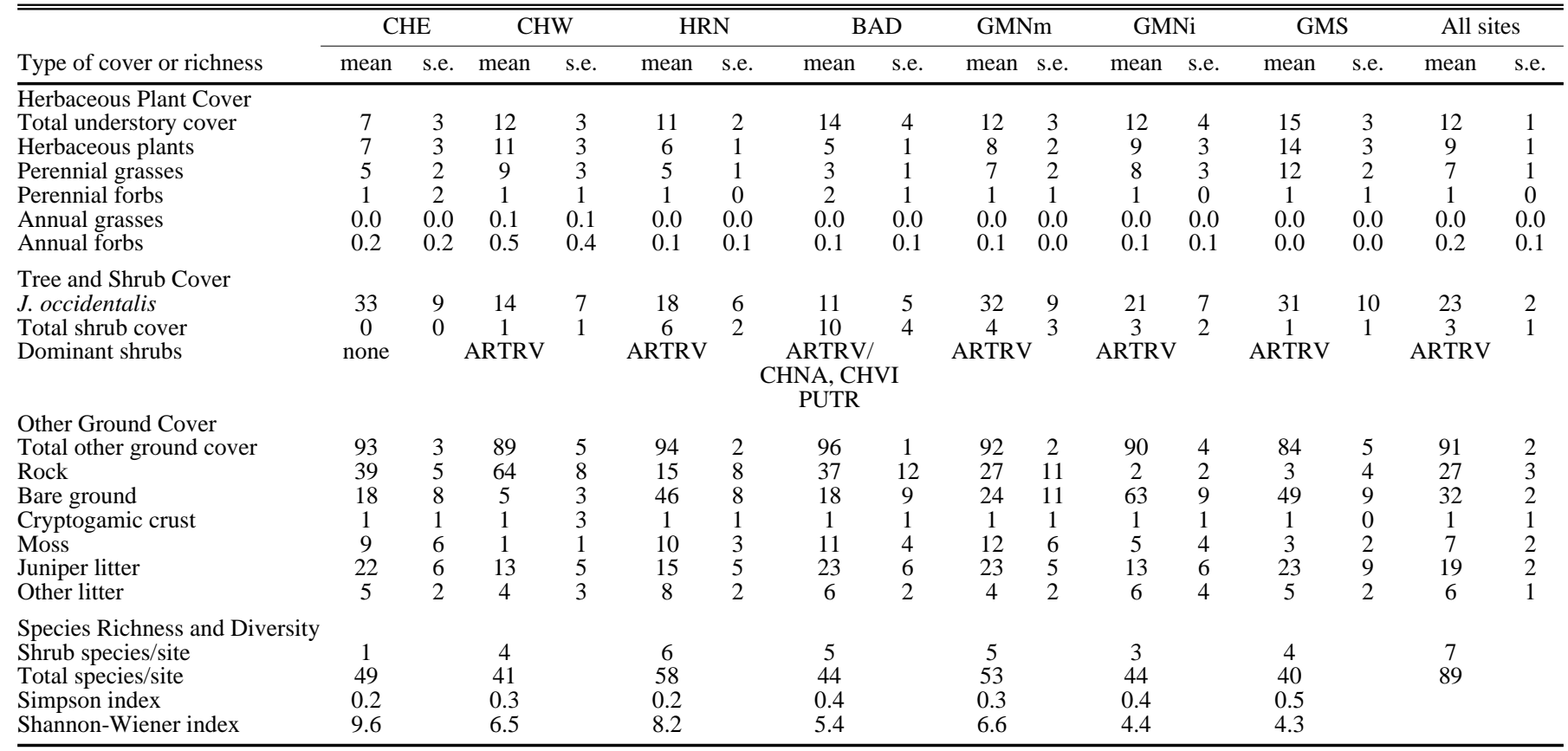

Shrub cover averaged $3 \%$ (range from 0 to $10 \%$ ). Mean density was 2,829 live shrubs ha ${ }^{-1}$. Dead shrubs average 869 ha $^{-1}$. On a site basis, live shrubs constituted between 24 and $73 \%$ of all shrubs. The most abundant shrubs were mountain big sagebrush and gray and green rabbitbrush with bitterbrush and horsebrush occurring on more than one site.
Herbaceous vegetation accounted for only $9 \%$ (range 5 to $14 \%$ ) of total ground cover. The majority of ground cover characterizing these stands was predominately bareground, rock, and juniper litter. Perennial grasses dominated the herbaceous layer with $7 \%$ mean cover across the sites. Idaho fescue and bluebunch wheatgrass were dominant grasses with junegrass (Koeleria cristata (Ledeb.) Schult.), Sandberg bluegrass, squirreltail (Sitanion hystrix (Nutt.) Smith), and Thurber needlegrass commonly present. Perennial forbs averaged $1 \%$ cover. The most abundant forbs were thread stalk milkvetch (Astragalus filipes Torr.), rock gilia, and silvery lupine (Lupinus argentus Pursh.) followed by wooly groundsel

Table 3. Woody plant densities and other tree attributes. Densities are given in number/ha.

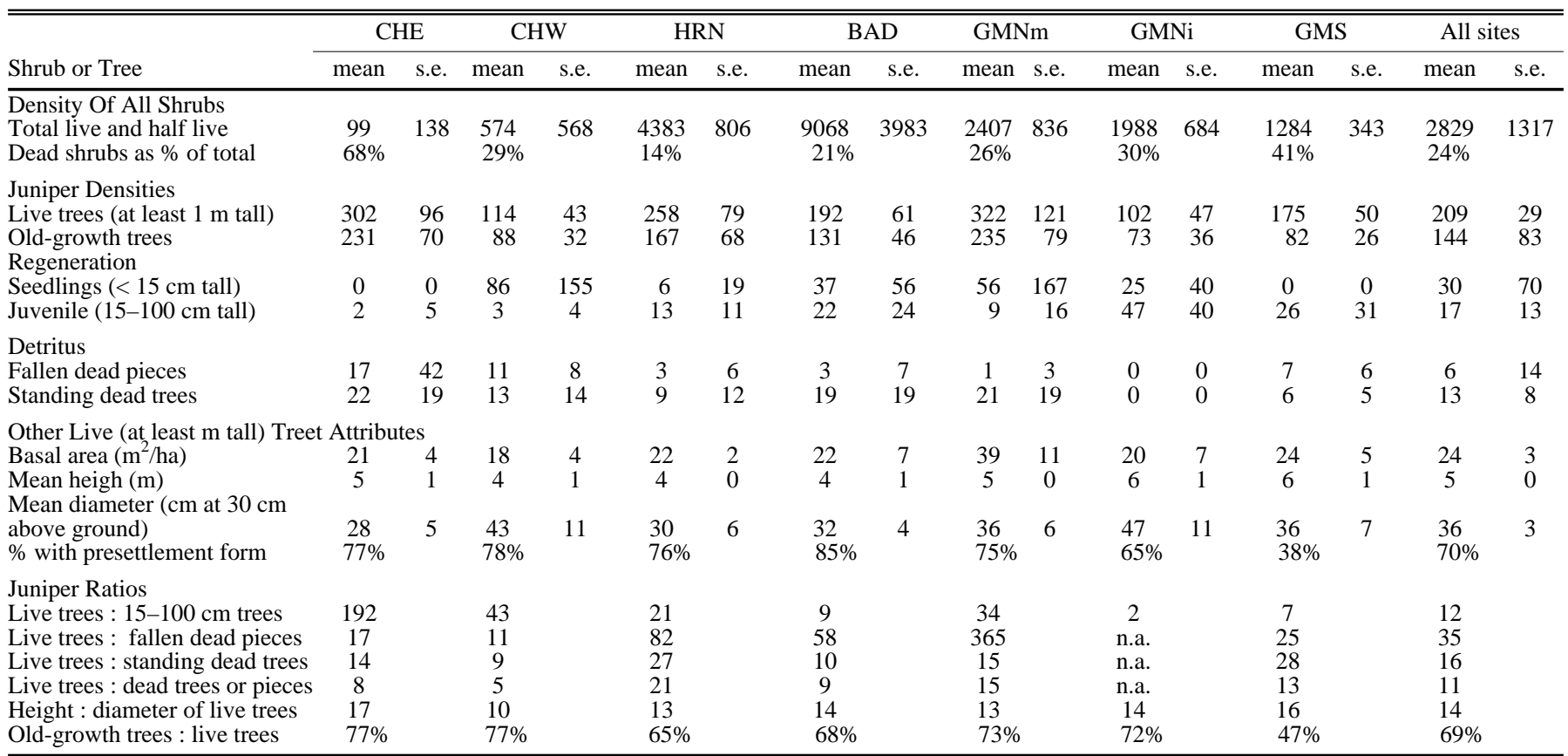




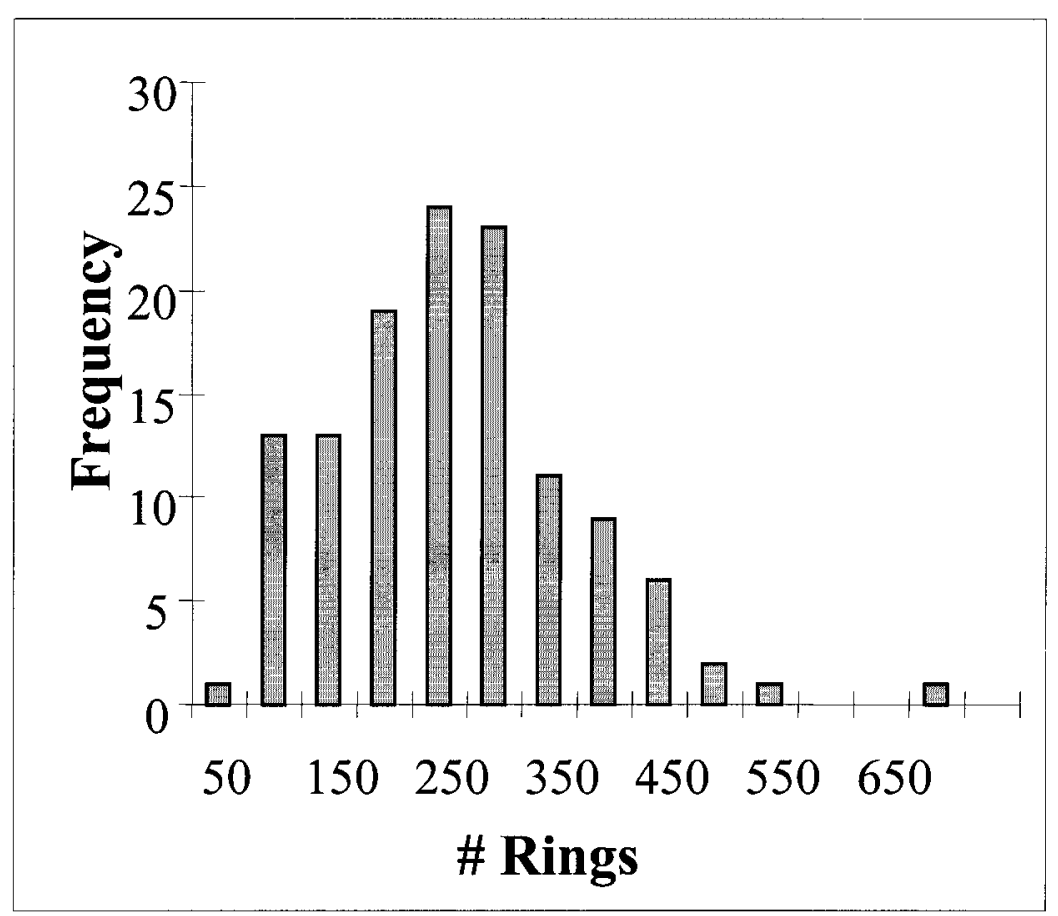

Fig. 2. Growth ring counts of trees sampled in plot. Ring counts are based on incomplete samples for most trees $>\mathbf{2 5 0}$ years due to rot, so ages are underestimated.

(Senecio canus Hook.), low pussytoes (Antennaria dimorpha (Nutt.) T. \& G.), threadleaf fleabane (Erigeron filifolius Nutt.), and alkali buckwheat (Eriogonum strictum Benth). Annual species cover was less than $1 \%$ at all 7 sites. No individual annual species exceeded $0.10 \%$ cover at any site.

Plant community diversity was more variable than the number of species found at a site (Table 2). Species richness ranged from 41 to 58 species. At the site level, the Simpson diversity index varied from 0.16 to 0.47 , while the Shannon-Wiener index ranged from 4.3 to 9.6 .

\section{Tree age and form}

Sixty-nine percent of all the trees measured $(n=1132)$ across the 7 sites were grouped as presettlement based on growth form. Among sites, $\geq 65 \%$ of trees $>1 \mathrm{~m}$ in height were presettlement. However, $78 \%$ of the successfully cored trees $(\mathrm{n}=$ 123) across all 7 sites had more than 130 rings (Fig. 2). Eleven percent of the trees cored, which were classified as postsettlement, had greater than 130 growth rings. Among these 13 trees, 8 ranged in age between 138 and 164 years, 2 between 178 and 192, and 3 between 206 and 250 years. The persistence of conical-shaped canopies in some trees caused us to underestimate the number of presettlement trees using growth form. Across all sites there was a sharp decline in samples collected with greater than 270 rings due to the onset of heartwood rot in the 1730s. This phenomena was reported across a relatively extensive area for western juniper by Knapp and Soule (1999). Trees for which complete or nearly complete cores were obtained had a median ring count of 288 years. This is a highly conservative estimate of the average tree age, as the sample was biased toward younger trees by the difficulty of obtaining complete cores in older trees.

Eighty percent of the trees sampled had over $50 \%$ of their leaf canopy still alive, with $31 \%$ of the stand having over $90 \%$ of their canopies intact. Trees with less than half of their leaf canopy intact accounted for $20 \%$ of the stand. Postsettlement trees predominantly had full canopies, with $80 \%$ having over $90 \%$ of their canopy. Although postsettlement trees had a greater portion of their leaf canopies intact, the percent of live or dead canopy was not a good attribute to separate presettlement and postsettlement trees.

\section{Species Composition}

The relationship between understory species composition with other plot attributes, such as soil texture, elevation, and slope, arranged the 7 sites into groups occupying different sectors of ordination space, using 3-dimensional NMS ordina- tion (Fig. 3). The axis numbers were assigned arbitrarily for this figure, since NMS does not arrange axes in order of importance.

Results from ordination were significant (Monte Carlo p-value $=0.05$, correlation coefficient for ordination distance and distance in the original 56-dimensional space $=0.83$ ). The Connley Hills, Horse Ridge North, and Badlands sites occupy separate sectors of the ordination space. There was some overlap between the east and west Connley Hills sites. The Green Mountain sites were less distinct, overlapping with the Connley Hills and Horse Ridge. The 2 Green Mountain north sites intermingled and the south site overlapped with the north-interspace site.

Correlation's between species composition and other plot attributes were seen in vectors overlaid on the ordination. The ordination axes were correlated with site topography, ground covers other than vascular plants, species richness, total understory cover, and the tree parameters density, mean height, mean diameter, basal area, and canopy area. Figure 3 shows overlays of vectors for the variables that had correlation coefficients of 0.30 or greater with any axis. The strongest correlation between plant species composition within communities and abiotic parameters were, in declining order, $\%$ sand in soil (correlation with Axis $1=0.70$ ), elevation (0.59 with Axis 1$), \%$ clay in soil (0.53 with Axis 2$)$, slope (0.46 with Axis $1)$, rock cover ( 0.45 with Axis 2$)$, and heat load ( 0.40 with Axis 2$)$. The high correlation of bare ground with community composition (0.36 with Axis 2) likely reflected a combination of cause and effect.

Most tree parameters correlated poorly (correlation coefficient $<0.10$ ) with axes determined from species composition. The exception was tree height ( 0.48 with Axis $3)$. This suggests that tree height was responsive to the same environmental factors that affect understory composition. Tree density showed no correlation $(<0.03$ with each axis) with understory composition.

Regression analysis showed little relationship between tree parameters and understory composition. Of tree density, cover, basal area, and litter, only density of trees $>1 \mathrm{~m}$ tall had a significant correlation with any understory attributes. An increase of 100 trees ha ${ }^{-1}$ corresponded to a decease of only $1 \%$ perennial grass cover $(\mathrm{p}=$ $0.0012)$ and an increase in species richness of $2(\mathrm{p}=0.0006)$. This again would suggest that differences in site potential such as soil texture, slope, elevation, and heat load were primary factors determining species composition and cover. 


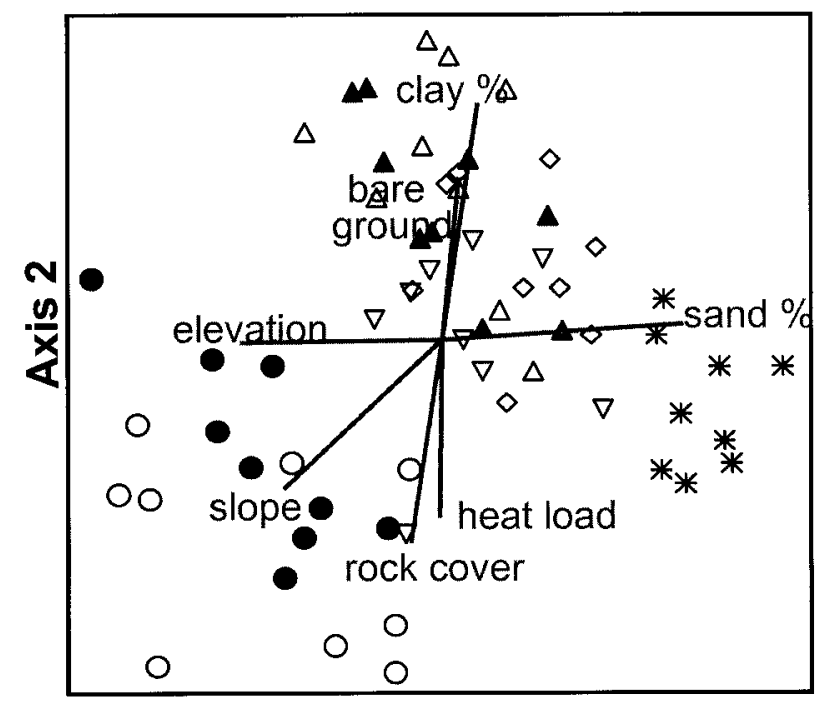

Axis 1

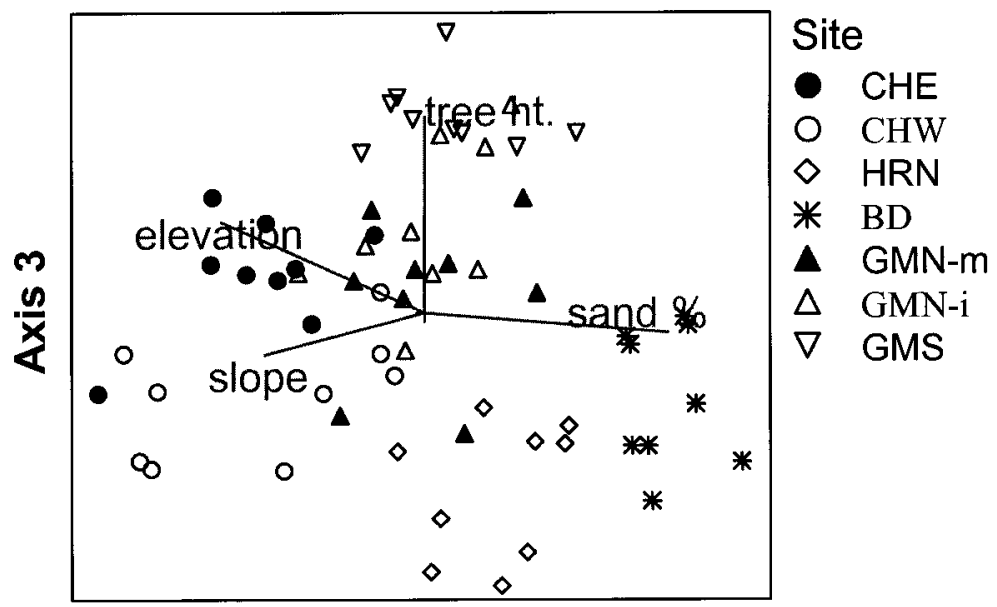

Axis 1

Fig. 3. Arrangement of plots in 3-D ordination space, with overlays of site attributes having $42>0.30$ or greater with any axis. Vectors are scaled in proportion to $r^{2}$. For example, the correlation between elevation and Axis 1 is $\mathbf{0 . 5 9 4}$ in the negative direction. Loops surround plots by area. Areas are; GRN - Green Mountain North mound (m) and interspace (i); GMS - Green Mountain south, GMW - Green Mountain west, CHE - Connley Hills east and CHW - Connley Hills west, HRN - Horse Ridge north, BD - Badlands. and sand content and decreased with increasing slope and elevation. Rock gilia correlated with the sand content gradient. Junegrass and alkali buckwheat correlated positively with elevation and negatively with sand content. Thread stalk milkvetch increased with elevation and slope and decreased with increasing sand content. Compared to these species, correlations of the ordination axes and cover by functional group were weaker. Perennial grass (0.26 with Axis 2 and 0.20 with Axis 3), and annual forbs ( 0.26 with Axis 1$)$ had the highest correlations.

\section{Discussion}

This study provided the basis for development of a quantitative old-growth western juniper woodland description, within the aeolian sand region in central Oregon. Old-growth woodlands in central Oregon contained a minimum density of 80 presettlement trees $\mathrm{ha}^{-1}$. These trees were typically over $16 \mathrm{~cm}$ in diameter, contained less than $90 \%$ of a full canopy, and exhibited morphological characteristics of oldgrowth trees. However, $11 \%$ of the trees retained the postsettlement growth form with symmetrical conical canopy shapes, several 200 years. Tree canopy cover ranged between 11 and $33 \%$ with tree basal areas varying from 18 to $39 \mathrm{~m}^{2} \mathrm{ha}^{-1}$. Dead wood within the stand was primarily retained as detritus in live trees and as standing dead trees. A minimum of 6 standing dead trees $\mathrm{ha}^{-1}$ (25 $\mathrm{cm}$ diameter) and 1 large (3.3 m length and $25 \mathrm{~cm}$ diameter) downed piece $\mathrm{ha}^{-1}$ occurs. Plant structure in these old-growth woodlands was different that nearby postsettlement woodlands described by Driscoll (1964a, 1964b) (Table 4).

Tree parameters generally correlated poorly with understory structure and composition. This may have been due to; (1)
Numerous individual species responded to the same gradients as the overall communities in the NMS ordination, as shown in Figure 4. Two dominant grasses responded along the clay content gradient, with Idaho fescue showing a strong positive correlation ( 0.44 with Axis 2$)$ and bluebunch wheatgrass showing a similarly strong, but negative, correlation (0.48). Other species responding to soil clay content were Ross sedge (Carex rossii Boott), Thurber needlegrass, cheatgrass (Bromus tectorum L.), and broom buckwheat (Eriogonum vimineum Dougl.). Mountain big sagebrush increased along with clay
Table 4. Comparison of old-growth Juniperus occidentalis communities to earlier seral communities in central Oregon described by Driscoll (1964a, 1964b).

\begin{tabular}{lccc}
\hline \hline Parameter & $\begin{array}{c}\text { Driscoll A } \\
\text { The Island }\end{array}$ & $\begin{array}{c}\text { Driscoll B } \\
\text { average (range) }\end{array}$ & Old-growth sites \\
\hline Juniper cover & $10 \%$ & $12 \%$ & $23 \%(11-33 \%)$ \\
Shrub cover & $10 \%$ & $7 \%$ & $3 \%(0-10 \%)$ \\
Shrub species & 2 & $\geq 3$ & 4 \\
Perennial grass cover & $13 \%$ & $13 \%$ & $7 \%(3-6)$ \\
Perennial forb cover & $1 \%$ & $4 \%$ & $1 \%(1-2 \%)$ \\
Annuals cover & $2.4 \%$ & $0.1 \%$ & $0.2 \%(0.0-0.6 \%)$ \\
$\begin{array}{l}\text { Species richness } \\
\text { total species noted) }\end{array}$ & 32 & not noted & $47(40-58)$ \\
Bare ground & $42 \%$ & not noted & $32 \%(5-63 \%)$ \\
Litter cover & $31 \%$ & not noted & $25 \%(17-29 \%)$ \\
\hline
\end{tabular}




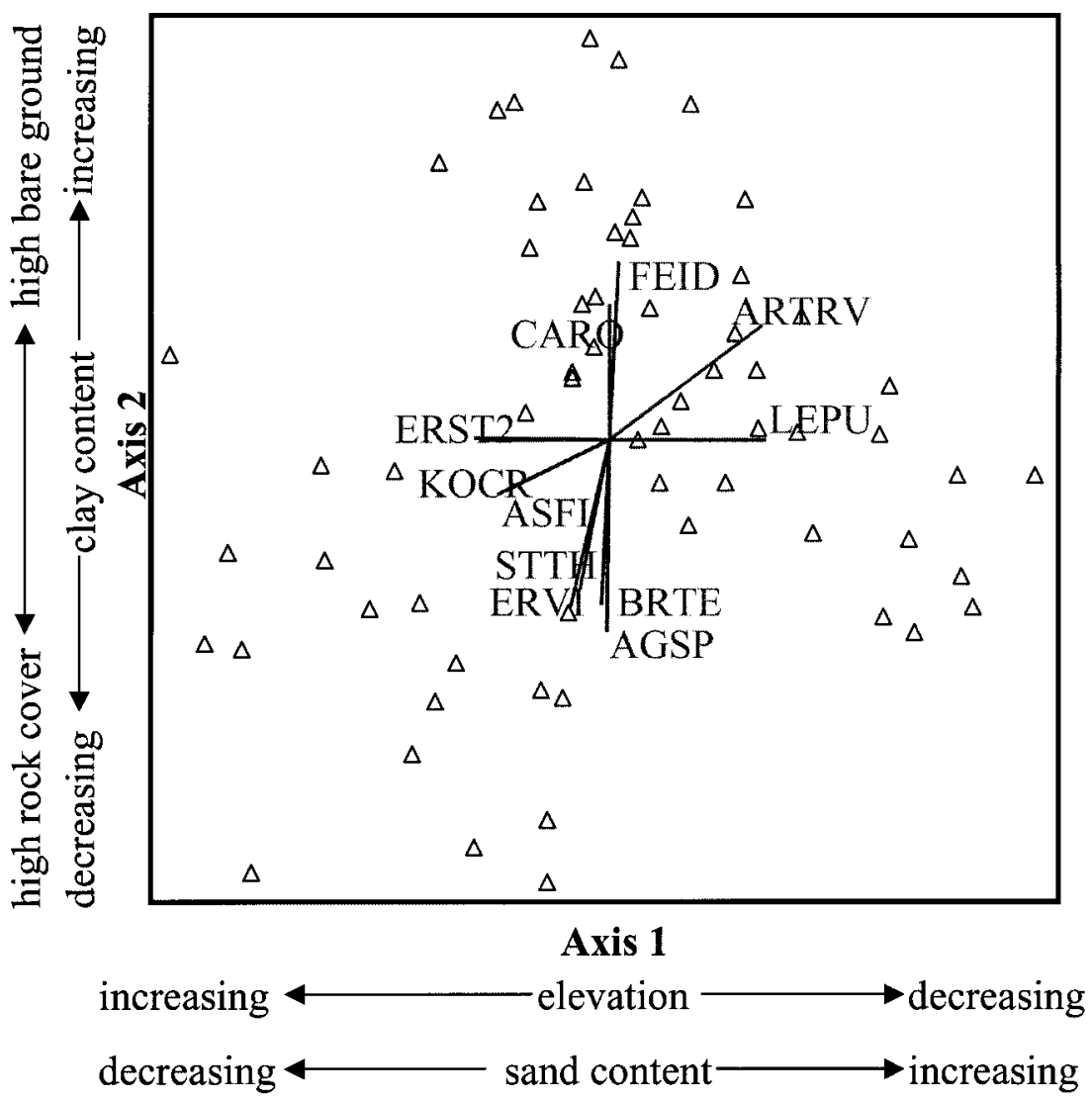

Fig. 4. Overlay of species with highest correlations with ordination axis. Species shown have $\mathbf{r}^{2} \geq 0.30$ with 1 or more axis. Species shown are Festuca idahoensis (FEID), A. spicatum (AGS), Artemisia tridentata (ARTRV), Astragalus filipes (ASFI), Bromus tectorum (BRTE), Carex rossii (CARO), Eriogonum strictum (ERST2). Eriogonum vimineum (ERVI), Koeleria cristata (KOCR), Leptodactylon punguns (LEPU), and Stipa thurberiana (STTH). Vectors are sized in proportion to the correlation coefficient, eg $\mathbf{r}^{2}=0.479$ for AGSP with Axis 2 . Only Lupinus argentus and Antennaria dimorpha had $\mathrm{r}^{2} \geq 0.302$ with Axis 3 (both positive correlations).

the limited range in tree canopy cover (11 to $33 \%$ ) among sites sampled, which was not broad enough to compensate for understory variability, (2) juniper trees were at or near full occupation, or (3) site factors such as soils were more important determinants of herbaceous cover and composition. The low shrub canopy cover (0 to $10 \%)$ and tight ring growth of understory trees across most of the study sites indicated stands were in the final stages of woodland development. Miller et al. (2000) reported perennial grass cover did not decrease with increasing juniper cover on deep well drained soils. They also reported low levels of shrub cover in stands approaching the final stages of woodland development where overstory trees dominated the site.

Stand replacement disturbances such as fire appeared not to have played a role in the formation of old-growth woodlands in the eolian sands region of central Oregon. All of the stands we measured were uneven aged, suggesting the absence of a spaced ladder fuels (shrubs), and open tree canopies greatly reduce the probability of low intensity or stand replacement fires in old-growth juniper woodlands occupying the aeolian sands.

Tree canopy cover in these old-growth juniper stands equaled or exceeded the minimum percent canopy of $10 \%$ used by the US Forest Service to define woodlands. In the Mazama Ecological Province oldgrowth stand structure was very different than the widely scattered presettlement trees in stands reported in the High Desert, Klamath, Humboldt, and Snake River Ecological Provinces (Fig. 1) (Holmes et al. 1986, Miller and Rose 1995, 1999). In these provinces old trees are typically found growing on rimrock or low sagebrush (Artemisia arbuscula Nutt.)/Sandberg bluegrass tablelands characterized by shallow rocky clay soils and tree canopy cover < $10 \%$. Old-growth was rarely found on sites supporting mountain big sagebrush.

Several distinct differences were noted between our old-growth western juniper stands and those reported for pinyonjuniper communities (Table 5). These descriptions have primarily been developed for the southwestern USA, where the pinyon-juniper definition applies to any mix of the 2 genera, including juniper alone. Western juniper densities among the 7 sites we studied equaled or exceeded the definition developed for pinyonjuniper. Minimum tree basal areas in the plots were also substantially greater in western juniper stands. However, canopy cover and minimum tree diameter were less among the old-growth western juniper woodlands than in the pinyon-juniper. Other live tree parameters were consistent with the pinyon-juniper definition. Woody detritus was more abundant and a greater proportion distributed in standing trees for western juniper woodlands than pinyonjuniper. The average density at all juniper sites was 13 standing dead trees and 6 downed pieces $\mathrm{ha}^{-1}$, while the pinyonjuniper definition specifies 2.5 standing dead and 5 downed pieces ha ${ }^{-1}$. The abundance of woody detritus may be a function of turnover rate and, or stand age.

Comparison of old-growth western juniper and ponderosa pine provides a sense of how old-growth character can change as a result of local site differences (Table 5). Ponderosa pine occurs in central Oregon in areas with similar elevations and slightly greater precipitation, often overlapping in range with western juniper. The definition of ponderosa pine oldgrowth developed for Oregon and other USFS Region 6 states, illustrates wide dif- 
Table 5. A comparison between Juniperus occidentalis old-growth woodlands with old-growth pinyon-juniper (Mehl 1992) and Pinus ponderosa (USDA Forest Service 1993).

\begin{tabular}{|c|c|c|c|}
\hline Parameter & $\begin{array}{l}\text { J. occidentalis } \\
\text { old-growth based } \\
\text { on } 7 \text { sites }\end{array}$ & $\begin{array}{l}\text { Pinyon-juniper } \\
\text { old-growth }\end{array}$ & $\begin{array}{l}\text { Pinus ponderosa } \\
\text { old-growth }\end{array}$ \\
\hline $\begin{array}{l}\text { Old-growth tree density } \\
\text { (overstory trees/ha) }\end{array}$ & 80 & 74 & $\begin{array}{l}25 \text { trees/ha or } \\
5 \text { trees/ha (late seral) }\end{array}$ \\
\hline Minimum diameter & $\begin{array}{l}16 \mathrm{~cm} \text { and } \leq 90 \% \\
\text { of full canopy }\end{array}$ & $30 \mathrm{~cm}$ at root collar & $\begin{array}{l}53 \mathrm{~cm} \text { breast } \\
\text { height or } 79 \mathrm{~cm} \\
\text { (late seral) }\end{array}$ \\
\hline $\begin{array}{l}\text { Minimum age of old- } \\
\text { growth trees }\end{array}$ & 200 years & 200 years & $\begin{array}{l}150 \text { years or } \\
200 \text { years (late seral) }\end{array}$ \\
\hline Decadence present & yes & yes & yes (late seral) \\
\hline Number of canopies & 1 & 1 & 1 \\
\hline Variation in tree diameters & yes & yes & yes \\
\hline $\begin{array}{l}\text { Minimum tree basal area } \\
\left(\mathrm{m}^{2} / \mathrm{ha}\right)\end{array}$ & 18 & 5.3 & not specified \\
\hline $\begin{array}{l}\text { Standing dead trees/ha, } \\
\text { (minimum diameter }\end{array}$ & $\begin{array}{c}6 \\
(25 \mathrm{~cm})\end{array}$ & $\begin{array}{c}2.5 \\
(25 \mathrm{~cm})\end{array}$ & $\begin{array}{l}7.5 \\
(36 \mathrm{~cm} \mathrm{DBH})\end{array}$ \\
\hline $\begin{array}{l}\text { Down wood pieces/ha, } \\
\text { (minimum size) }\end{array}$ & $\begin{array}{l}1 \text { ( } 3 \text { m long, }(25 \\
\mathrm{cm} \text { diameter at } \\
\text { one end })\end{array}$ & $\begin{array}{c}5 \text { (3m long, } 25 \mathrm{~cm} \\
\text { diameter at one } \\
\text { end) }\end{array}$ & $0^{(1)}$ \\
\hline Total canopy cover & $10-35 \%$ & $35 \%$ & not specified \\
\hline $\begin{array}{l}\text { Understory canopy } \\
\text { cover }\end{array}$ & $<20 \%$ & not indicated & $20-40 \%$ typical \\
\hline
\end{tabular}

${ }^{1}$ The lack of required down wood reflects the natural role of fire in the Pinus ponderosa community. Otherwise, typical values are 8 to 15 pieces greater than $2.45 \mathrm{~m}$ long and $30 \mathrm{~cm}$ in diameter.

ferences in stand structural characteristics in comparison to old-growth juniper. Trees in old-growth juniper are considerably smaller than the old-growth pines, but contain a higher density of overstory trees. The ratio of live old-growth trees to standing dead (standing live:dead) is greater in the western juniper woodland $(8.0$ versus 3.3). In addition, fallen dead trees are more abundant in the unburned pine forest. This possibly indicates a more rapid turnover of trees in the old-growth ponderosa pine stands.

A distinct contrast between old-growth western juniper woodlands and mesic oldgrowth conifer forests is the function of woody detritus. Woody detritus appears to function differently in western juniper woodlands than in more mesic old-growth systems. Dead wood is predominantly retained aloft throughout much or all of the decay process, as evidenced by tree boles that have been dead for up to 500 years and dead wood retained on live trees for up to 600 years. In comparison, the estimated time for $95 \%$ decay of fallen trees in the Pacific Northwest is 273 years for western hemlock (Tsuga heterophylla (Raf.) Sargent) or sitka spruce (Picea sitchensis (Bong.) Trautvetter and Mayer) and 429 years for Douglas-fir (Pseudotsuga menziesii (Mirbel) Franco) (Maser and Trappe 1984). Others have reported $3 \%$ annual decay rate of coarse woody debris in western Oregon forests (Solins 1982, Spies et al. 1988). Western juniper debris appears to deteriorate more through abiotic weathering than through biotic decomposition. This has a significant, and restrictive, impact on the functions of woody detritus in the old-growth community. Fungal activity appears to be limited. Large fungi were observed on the surface of the wood, but networks of fungal hyphae were not observed in wood in any stage of decay. Arthropods such as carpenter ants were also absent in woody debris across sites. Nitrogen fixation that occurs in moist, well-decayed woody debris in more mesic systems (Franklin et al. 1981) is likely absent or very limited in these more arid systems.

In the study plots, evidence of natural disturbance such as fire, insect infestation, or windstorm was absent or negligible. Anthropological disturbances included a small amount of woodcutting and cattle grazing. These disturbances did not appear to have impacted the structure of the sites.

\section{Defining Old-growth Woodlands}

Some of the western juniper woodlands occurring in central Oregon are older than generally believed and are clearly oldgrowth woodlands. Little has been known about these unique woodlands until now. These ancient woodlands should be identified and mapped so that management plans addressing the special qualities of old-growth can be prepared and implemented. Old-growth trees should be protected from anthropogenic disturbance until their resource values are addressed in management plans. However, criteria for delineating old-growth woodlands have been lacking.

Structural components that characterized old-growth juniper woodlands are easily identifiable. In the absence of major disturbance, structural characteristics including individual tree morphologies typical of old trees, standing and down dead, canopy decadence, abundance of lichen in the tree canopies, hollows, and cavities would be expected to increase over time. Rienkensmeyer (2001) reported cavity nesting birds were 2.7 times more abundant in old-growth than postsettlement juniper stands in central Oregon. These characteristics also distinguish oldgrowth stands from young post-settlement stands. However, at what point or threshold these characteristics delineate a stand as old-growth becomes subjective since development is a long continuous successional sequence. Criteria used by Woodgate et al. (1996) helps us define old-growth juniper. Using their old-growth model and based on our results we would define a relatively undisturbed old-growth juniper woodland as having; (1) $\geq 75 \%$ trees with one or more morphological characteristics expressed by old-growth (rounded tops, furrowed bark, > 10\% canopy decadence, strip bark, etc.), (2) $<10 \%$ regenerating trees in the understory, and (3) $<10 \%$ of the stand containing cut stumps and recently burned skeletons. Additional structural characteristics that can be used to delineate old-growth woodlands are; $\geq 6$ standing dead trees and $\geq 1$ down pieces of wood/ha, and lichen in the tree canopies is common (easily seen standing in 1 location). Juniper woodlands containing a predominance of old trees but not meeting the above criteria may reflect stands in earlier stages of old-growth development or locations of different site potentials. The woodlands in this study appeared to have negligible disturbance.

Old-growth juniper woodland characteristics will vary spatially, across soil types and landscape locations, and temporally with stand age. Stand characteristics are highly location specific even within the pumice-dominated soils of this study area. The 7 sites studied differed in structure and composition. Management plans should recognize that such variability occurs within some old-growth woodlands. A full working definition of old- 
growth western juniper woodlands needs to consider the range of soils where oldgrowth juniper occurs, plant communities with different understory dominants, and the acceptable limits of natural and anthropogenic disturbance.

\section{Literature Cited}

Anderson, E.W., M.M. Borman, and W.C. Krueger. 1998. The ecological provinces of Oregon-a treatise on the basic ecological geography of the state. Oregon Agr. Exp. Sta.

Bolsinger, C.L. 1989. California's western juniper and pinyon-juniper woodlands: area, stand characteristics, wood volume and fenceposts. USDA For. Serv. Resource Bull PNW-RB-166

Burkhardt, J.W. and E.W. Tisdale. 1969. Nature and successional status of western juniper vegetation in Idaho. J. Range Manage. 22:264--270.

Burkhardt, J.W. and E.W. Tisdale. 1976. Causes of juniper invasion in southwestern Idaho. Ecol. 76:2-484.

Canfield, R. 1941. Applications of the line intercept method in sampling range vegetation. J. Forestry 39:388-394.

Cronquist, A., A.H. Holmgren, N.H. Holmgren, J.L. Reveal, and P.K. Holmgren. 1977. Intermountain flora. New York Botanical Garden, Bronx, N.Y.

Driscoll, R.S. 1964a. A relict area in the central Oregon juniper zone. Ecol. 45:345-353.

Driscoll, R.S. 1964b. Vegetation-soil units in the central Oregon juniper zone. USDA For. Ser. Res. Pap. PNW-19.

Franklin, J.F., K. Cromack, W. Denison, A. McKee, C. Maser, J. Sedell, F. Swanson, G. Juday. 1981. Ecological characteristics of old-growth Douglas-fir forests. USDA For. Serv. Gen. Tech. Rep. PNW-118.

Gedney, D.R., D.L. Azuma, C.L. Bolsinger, and N. McKay. 1999. Western Juniper in eastern Oregon. USDA For. Ser. PNW-GTR464.

Gee, G.W. and J. W. Bauder. 1986. Particle size analysis. pp 404-407 In: Methods of soil analysis. Part 1 - Physical and mineralogical methods. $2^{\text {nd }}$ edition. A. Klute, editor. Amer. Soc. of Agron. and Soil Sci. Soc. of Amer. Madison Wisc..

Hitchcock, C.L. and A. Cronquist. 1973 Flora of the Pacific Northwest. Univ. Washington Press, Seattle, Wash.

Holmes, R.L., R.K. Adams, and H.C. Fritts 1986. Tree-ring chronologies of western North America: California, eastern Oregon and northern Great Basin. Lab. of Tree-Ring Res., Univ. of Arizona Chronology Series VI.

Houston, D.B. 1973. Wildfires in northern Yellowstone National Park. Ecol. 54:1109-1117.
Kaufmann, M.R., W.H. Moir, W.W. Covington. 1992. Old-growth forests: what do we know about their ecology and management in the southwest and rocky mountain regions? pp. 1-11 In: Old-growth forests in the southwest and rocky mountain region: proceedings of a workshop. USDA For. Ser. Gen. Tech. Rep. RM-213.

Knapp, P.A. and P.T. Soule. 1999. Geographical distribution of an $18^{\text {th }}$-century heart rot outbreak in western juniper (Juniperus occidentalis spp. occidentalis Hook.). J. Arid Environ. 41:247-256.

Kruskal, J.B. 1964. Nonmetric multidimensional scaling: a numerical method. Psycometrika 29:115-129.

Martin, R.E. and A.H. Johnson. 1979. Fire management of Lava Beds National Monument, p 1209-1217. In: R. E. Linn (ed.) Proc. First Conf. Sci. Res. Nat. Parks. USDI Nat. Parks Ser. Trans. Proc. Ser. No. 5.

Maser, C. and J.M. Trappe, editors. 1984. The seen and unseen world of the fallen tree. USDA Forest Serv. Gen. Tech. Rep. PNW164.

Mather, P.M. 1976. Computational methods of multivariate analysis in physical geography. J. Wiley and Sons, London. 532 pp.

McCune, B. and M.J. Mefford. 1995. PCORD for Windows: Multivariate analysis of ecological data. Version 3.03. MjM Software Design, Gleneden Beach, Ore.

Mehl, M.S. 1992. Old-growth descriptions for the major forest cover types in the rocky mountain region. pp.106-120 In: Old-growth forests in the southwest and rocky mountain region: proceedings of a workshop. USDA For. Serv. Gen. Tech. Rep. RM-213.

Miller, R. F. and J. A. Rose. 1995. Historic expansion of Juniperus occidentalis (western juniper) in southeastern Oregon. Great Basin Natur. 55:37-45.

Miller, R.F. and J.A. Rose. 1999. Fire history and western juniper encroachment in sagebrush steppe. J. Range Manage. 52:550-559.

Miller, R. F. and P.E. Wigand. 1994. Holocene changes in semiarid pinyon-juniper woodlands. BioSci. 44:465-474.

Miller, R.F., T.J. Svejcar, and J.A. Rose. 2000. Impacts of western juniper on plant community composition and structure. J. Range Manage. 53:574-585.

Miller, R.F., R.J. Tausch, and W.S. Waichler. 1999. Old-growth juniper and pinyon woodlands. pp. 375-384 In: Monsen, S.B., S. Richards, R.J. Tausch, R.F. Miller, C. Goodrich, (comp.); Proc.-Ecology and Management of Pinyon-Juniper Communities Within the Interior West. USDA For. Ser., RMRS-P-9.

Rienkensmeyer, D.P. 2001. Habitat associations of bird communities in shrub-steep and western juniper woodlands. M.S. Thesis. Oregon State Univ. Corvallis, Ore.

SAS. 1996. SAS-STAT user's guide. SAS Institute, Inc., Cary, N.C.

Sollins, P. 1982. Input and decay of coarse woody debris in coniferous stands in western Oregon and Washington. Can. J. For. Res. 12:18-28.
Spies, T.A., Franklin, J.F. and T.B. Thomas. 1988. Coarse woody debris in Douglas-fir forests of western Oregon and Washington. Ecol. 69:1689-1702.

Taylor, G.H. 1993. Normal annual precipitation; state of Oregon. Oregon Climate Service, Oregon State Univ., Corvallis, Ore.

USDA Forest Service. 1993. Interim old growth definition for Douglas-fir series, grand fir/white fir series, interior Douglas fir series, lodgepole pine series, pacific silver fir series, ponderosa pine series, Port-Orfordcedar and tanoak (redwood) series, subalpine fir series, western hemlock series. USDA For. Ser. Region 6.

USDI Bureau of Land Management. 1990. The juniper resources of eastern Oregon . USDI Bureau of Land Manage. Infor. Bull. OR-90-166.

Waichler, W.S. 1998. Community structure of old-growth Juniperus occidentalis woodlands. M.S. Thesis Oregon State Univ., Corvallis, Ore.

Woodgate, P.W., B.D. Peel, J.E. Coram, S.J. Farrell, K.T. Riman, and A. Lewis. 1996. Old-growth forest studies in Victoria, Australia concepts and principles. For. Ecol. Manage. 85:79-94. 